\title{
Chocolate Suburb, Vanilla Power: Race, Space and Civil Unrest in Ferguson
}

\section{Chanhaeng Lee}

Sungkyunkwan University

\begin{abstract}
In this article, I argue that the demographic and political restructuring of city-suburb dynamics in the United States is key to understanding what happened in Ferguson, Missouri, in the summer of 2014. Ferguson, a once-vanilla suburb where the overwhelming majority of residents were white Americans, was deterritorialized from the 1970s onward into a suburb where black Americans became the majority group. However, the whites, as a demographic minority, were still in control and tried to reterritorialize the black suburb. I maintain that the inevitable result of this disjunction between the chocolate suburb and vanilla power was racial antagonism, which exploded in Ferguson in 2014.
\end{abstract}

Keywords: Ferguson, Chocolate Suburb, Vanilla Power, Deterritorialization, Reterritorialization, Ecology of Power

Many still vividly remember the shooting of black teenager Michael Brown, who was killed in Missouri by a white police officer, Darren Wilson, on August 9, 2014. ${ }^{1}$ Born in an impoverished suburban area named Ferguson,

1 The author has no offensive intent in using the terms "chocolate" and "vanilla." These terms came into use in 1975 when George Clinton, the leader of the funk band Parliament, wrote a song titled "Chocolate City." In this song, Clinton celebrated black urbanization as black domination of the inner city by suggesting that "A chocolate city is no dream / It's my piece of the rock and I dig you, CC / God bless Chocolate City and its (gainin' on ya!) vanilla suburbs." These terms were also adopted by sociologists to describe racial residential segregation in urban America. See Reynolds Farley, Howard Schuman, Suzanne Bianchi, Diane Colasanto, and Shirley Hatchett, "Chocolate City, Vanilla Suburbs: Will the Trend toward Racially 
Brown had recently graduated from Normandy High School in the northern St. Louis County in Missouri and was two days away from starting college. The Brown-Wilson case and subsequent outbreak of urban disturbance became a national issue during the summer of 2014 and generated numerous interpretations of the causes of the Ferguson incident. Until now, most of these interpretations have focused on the racism displayed by white police officers, ${ }^{2}$ while a different point of view has concentrated on suburban poverty and racial segregation as a root cause of the Ferguson unrest. ${ }^{3}$ In contrast to these interpretations, I aim to discover historical causes for the Ferguson unrest in the demographic and political restructuring of cities and suburbs in the United States during the twentieth century. The findings of this study will conclude that the unrest in Ferguson, rather than an aberration, is in fact an unmistakable sign that urban-suburban restructuring can always develop into crisis, anywhere in the United States. ${ }^{4}$

To analyze the long-term historical changes and their consequences in Ferguson, this study applies the concepts of "deterritorialization" and "reterritorialization" from A Thousand Plateaus: Capitalism and Schizophrenia (1980) by French philosophers Gilles Deleuze and Félix Guattari. Deterritorialization, according to Deleuze and Guattari, is "the operation of the line of flight." It is "the complex movement or process by which something escapes or departs from a given territory, where a territory can be a system of any kind, conceptual, linguistic, social or affective." ${ }^{5}$ In other words, it is the process of undoing what has already been established. This study adopts the term deterritorialization to refer to a process in which Ferguson,

Separate Communities Continue?," Social Science Research 7 (1978): 319-344.

2 Darryl Pinckney, "In Ferguson," New York Review of Books, January 8, 2015; Vesla M. Weaver, "Black Citizenship and Summary Punishment: A Brief History to the Present," Theory \& Event 17, no. 3 supplement (2014).

3 Rigel Christine Oliveri, "Setting the Stage for Ferguson: Housing Discrimination and Segregation in St. Louis," University of Missouri School of Law Legal Studies Research Paper no. 2015-13, July 20, 2015; Richard Rothstein, "The Making of Ferguson: Public Policies at the Roots of Its Troubles," Economic Policy Institute Report, October 15, 2014; Colin Gordon, "Segregation's Long Shadow," Dissent, September 18, 2014; Elizabeth Kneebone, "Ferguson, Mo. Emblematic of Growing Suburban Poverty," Brookings Institution, August 15, 2014.

4 For insightful historical discussions of urban crisis, see Colin Gordon, Mapping Decline: St. Louis and the Fate of the American City (Philadelphia, PA: University of Pennsylvania Press, 2008); Thomas J. Sugrue, The Origins of the Urban Crisis: Race and Inequality in Postwar Detroit (Princeton, NJ: Princeton University Press, 1996).

5 Gilles Deleuze and Félix Guattari, A Thousand Plateaus: Capitalism and Schizophrenia (Minneapolis, MN: University of Minnesota Press, 1987), 508. 
a typical U.S. vanilla suburb mostly populated by white Americans until the late 1960s, was transformed into a chocolate suburb where the majority of residents are black. Meanwhile, Deleuze and Guattari argue that systems of any kind always have within themselves "vectors of deterritorialization," which are "inseparable from correlative reterritorializations." They define the process of reterritorialization as a movement that obstructs "the operation of the line of flight" and overlays the deterritorialized territory. ${ }^{6}$ Again, this study applies the term reterritorialization to indicate an attempt made by white people to consolidate and expand their power in deterritorialized Ferguson. The Ferguson unrest during the summer of 2014 was nothing less than the outcome of racial antagonism arising from the clash between these two conflicting movements: deterritorialization and reterritorialization.

By giving us a more focused lens through which to examine the dynamics of the U.S. city-suburb, Ferguson and the incidents that took place there provide us with important implications for rethinking the ideology of colorblindness. By 2014, U.S. society had matured to the point of electing a black president, but the Ferguson unrest clearly signals the fact that race still functions as a major channel of the unequal distribution of material wealth and power. Moreover, the Ferguson unrest is an undeniable piece of evidence that, despite the ongoing transformation of the U.S. into a multiracial society, the black-white relationship still holds primary importance among racial issues.

\section{The Deterritorialization of Ferguson: From a Vanilla Suburb to a Cho- colate Suburb}

In 1968, Larman Williams, a resident of Wellston, a black ghetto near St. Louis, purchased a house in Ferguson, a suburb of St. Louis about eight miles northwest of the downtown core. The suburb's racial makeup was predominantly white when Williams, an assistant principal, moved there. ${ }^{7}$ Prior to Williams's move to Ferguson, local residents had prevented black Americans from moving into the suburb, which was labeled a "sundown town" - in other words, a town in which black people were not even allowed to walk around freely at night. However, after Williams moved to

6 Ibid., 508-509. See also Paul Patton, Deleuzian Concepts: Philosophy, Colonization, Politics (Stanford, CA: Stanford University Press, 2010), 52.

7 Rothstein 2014,3. 
Ferguson, other blacks who were also in search of a better residential and educational environment for their families started moving in, causing this suburb's white wall of racial segregation to crack. During the 1970s, increasing numbers of blacks moved into Ferguson. Their migration deterritorialized this once-vanilla suburb and transformed it into one in which black people made up the overwhelming majority of residents. The building of an all-white Ferguson into the 1960s and its subsequent transformation reflect long-term historical trends in the spatial and demographic restructuring of twentieth-century U.S. city-suburb dynamics.

To borrow a theatrical term, the first act of these longue durée trends was the formation of a chocolate city with vanilla suburbs. A shortage of labor during the World Wars promoted the mingling of various races and ethnicities in workplaces. However, such encounters proved limited and temporary because the large-scale migrations of black Americans from the South to the North or from the farms to the cities generated "white flight," a phenomenon of whites leaving cities to move to suburbs. ${ }^{8}$ Together, the public sector, which includes the Federal Housing Administration (FHA), and the private sector, which includes banks and realtors, functioned as the financial supporters for the departure of the white residents. These institutions enabled white Americans to fulfill their desire to enter the middle class, and thus played a key role in creating racially segregated areas dubbed vanilla suburbs. The white persons who were able to move to these suburbs used racial zoning, restrictive covenants, and local controls to create racially homogeneous, clean, and well-maintained vanilla spaces. Furthermore, as demonstrated by California's Proposition 13 in 1978 to reduce property tax rates significantly, white people refused to pay the taxes that could have been used to resolve issues in poor metropolitan areas and formed themselves into conservative political groups to lead this anti-tax revolt. ${ }^{9}$ In

8 For recent scholarship on white flight, see Mark T. Mulder, Shades of White Flight: Evangelical Congregations and Urban Departure (New Brunswick, NJ: Rutgers University Press, 2015); Rachael A. Woldoff, White Flight/Black Flight: The Dynamics of Racial Change in an American Neighborhood (Ithaca, NY: Cornell University Press, 2011); Kevin M. Kruse and Thomas J. Sugrue, eds., The New Suburban History (Chicago, IL: University of Chicago Press, 2006); Kevin M. Kruse, White Flight: Atlanta and the Making of Modern Conservatism (Princeton, NJ: Princeton University Press, 2005); Eric Avila, Popular Culture in the Age of White Flight: Fear and Fantasy in Suburban Los Angeles (Berkeley, CA: University of California Press, 2004).

9 On California's tax revolt, see Arthur O'Sullivan, Terri A. Sexton, and Steven M. Sheffrin, Property Taxes and Tax Revolts: The Legacy of Proposition 13 (Cambridge, UK: Cambridge University Press, 1995); Terry Schwadron, ed., California and the American Tax Revolt: Proposition 13 Five Years Later (Berkeley, 
contrast, most black Americans could not move to the suburbs; their only alternative was to join the socioeconomically disadvantaged concentrated in poverty-stricken inner cities. After white residents had fled, these poor neighborhoods collapsed economically because businesses, supermarkets, and banks abandoned the gritty inner cities as well. The dwindling availability of various governmental support programs exacerbated the degeneration of these areas into wastelands. In these clearly contrasting dynamics of city and suburb, the blacks living in cities had the negative image of the ghetto overlain onto their own bodies.

St. Louis provided a main stage for the first act of this urban-suburban transformation. During the Jim Crow period, black people in the South headed to the industrial North in an attempt to avoid racial discrimination and poverty. Many of these black migrants settled in the St. Louis area, where the Mississippi River twists its way between the states of Missouri and Illinois. ${ }^{10}$ Most of this population settled either around Market Street, south of Delmar Boulevard, which today divides the city by race,,$^{11}$ or near Mill Creek Valley, which disappeared from the map in the late 1950s due to urban renewal. Some blacks also formed their own poor suburban enclaves in places near St. Louis such as Elmwood Park, Meacham Park, and Kinloch. ${ }^{12}$ World War II caused the black population in the St. Louis area to increase rapidly. It rose from slightly over 20,000 in 1880 to 180,000 by 1945 as black people moved in to participate in its active war economy. As in other regions, when the white persons confronted by the racial turn in St. Louis left the city, a spatial reorganization occurred: affluent vanilla suburbs were formed, leaving behind a poor chocolate city deprived of stable tax revenues. Moreover, as elsewhere, in St. Louis the FHA, along with

CA: University of California Press, 1984); David O. Sears and Jack Citrin, Tax Revolt: Something for Nothing in California (Cambridge, MA: Harvard University Press, 1982).

10 Although much smaller than St. Louis, East St. Louis, a booming industrial city located on the Illinois side of the Mississippi River, was also a popular destiny for black migrants. In East St. Louis, the black population increased from 513 in 1880, to 772 in 1890, and to 1,799 in 1900. This rapid influx of black Americans from the South to East St. Louis brought increased racial tensions and anxieties over labor and housing that led to the East St. Louis riot of 1917, a tragic white-instigated race riot which resulted in the deaths of at least 9 whites and 39 blacks. See Charles L. Lumpkins, American Pogrom: The East St. Louis Race Riot and Black Politics (Athens, OH: Ohio University Press, 2008), 13; Paul A. Gilje, Rioting in America (Bloomington, IN: Indiana University Press, 1996), 113.

11 Colin Gordon, "The Making of Ferguson," Dissent, August 16, 2014; Malcolm Gay, "White Flight and White Power in St. Louis," Time, August 13, 2014.

12 Colin Gordon, "How Racism Became Policy in Ferguson," Dissent, March 5, 2015. 
private sector components such as realtors, facilitated the desire of whites to move away from inner-city areas, to suburbs like Ferguson by assisting them financially while blocking opportunities for black Americans to join the migration. In doing so, they conspired to complete the first act of the spatial and demographic reorganization of the city and the suburb. During the 1960s, when urban riots swept across the United States, the Kerner Commission found that the United States was gradually moving toward two "separate and unequal" societies. ${ }^{13}$ This was the first act of the urban-suburban change.

The second act of this urban-suburban transformation began after the 1970s when urban black residents packed their belongings and moved to the suburbs. ${ }^{14}$ The black persons who began moving to the suburbs were those who, like Williams, wanted to find a better environment for their children's education and who had the financial ability to do so. Of course, this did not mean that suburban white Americans welcomed them. When Williams first went house-hunting in Ferguson, the realtor refused even to show him houses - the white residents did not want black people, regardless of whether they were middle class, in their neighborhoods. Williams finally succeeded in purchasing a house in Ferguson with the help of a white pastor from a church he attended. Meanwhile, during the 1970s, white homeowners in the suburbs near St. Louis began selling their homes to blacks more frequently. The realtors' greedy practice of blockbusting, in which they unscrupulously spread rumors that black residents would soon be flooding the white suburbs so that housing prices would decline, played a large role in influencing the growing number of white persons who sold their homes. ${ }^{15}$ In the end, the agency of the blacks to overcome residential discrimination on the one hand and the realtors' cunning tricks to maximize their profits on the other penetrated the white wall of racial segregation. As the number of black residents increased in this once-vanilla suburb, the whites moved to outer suburbs, the exurbs, or alternatively returned to newly gentrified urban areas that were now favored by the rich white population. As a result,

13 National Advisory Commission on Civil Disorders, Report of the National Advisory Commission on Civil Disorders (New York, NY: Bantam Books, 1968), 1.

14 Eugene L. Tettey-Fio, "Black American Geographies: A Perspective," in Race, Ethnicity, and Place in a Changing America, eds. John W. Frazier and Eugene L. Tettey-Fio (Binghamton, NY: Global Academic Publishing, 2006), 76-77.

15 Rothstein 2014, 25-26. 
the black population in Ferguson rose significantly from less than 1 percent in 1970 to 14 percent in 1980, 25 percent in 1990, 52 percent in 2000, and 67 percent in 2010, and the white populace in Ferguson declined rapidly from 74 percent of the suburb's population in 1990 to 29 percent in $2010 .{ }^{16}$

Maps showing changes in the African American population density of Ferguson, St. Louis, from 1970 to 2010

Source: http://worldmap.harvard.edu/mappingdecline/ (accessed April 18, 2015).

1970 Census Demographics of Ferguson, St. Louis

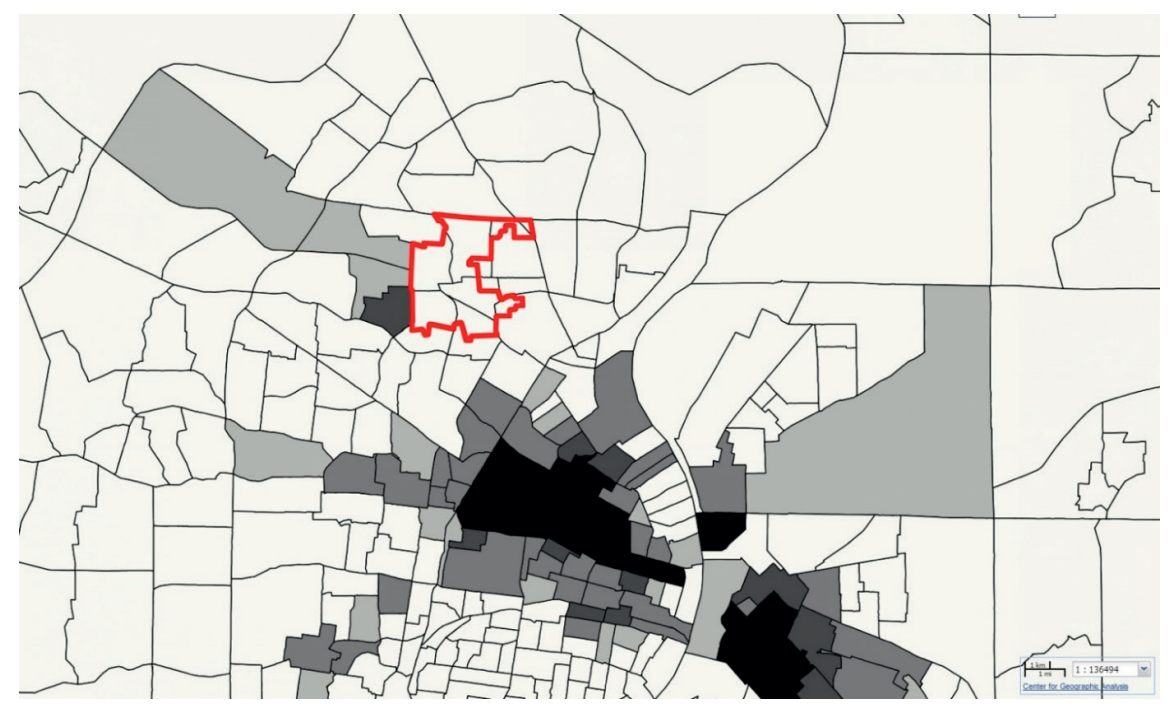


1990 Census Demographics of Ferguson, St. Louis

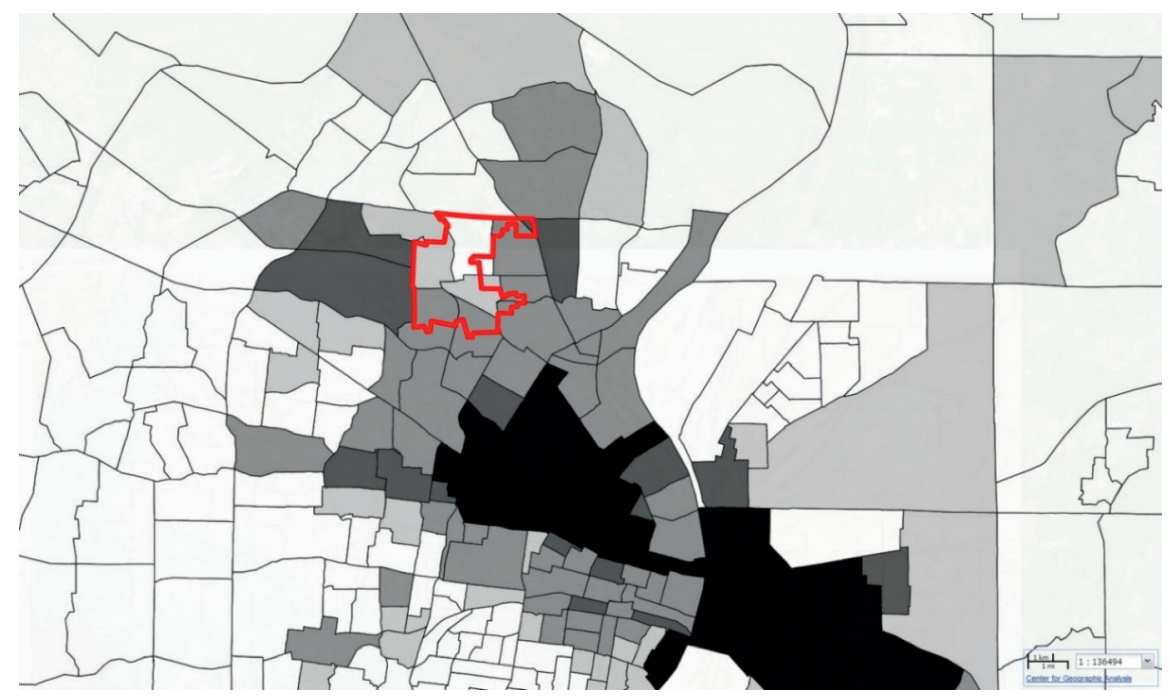

2010 Census Demographics of Ferguson, St. Louis

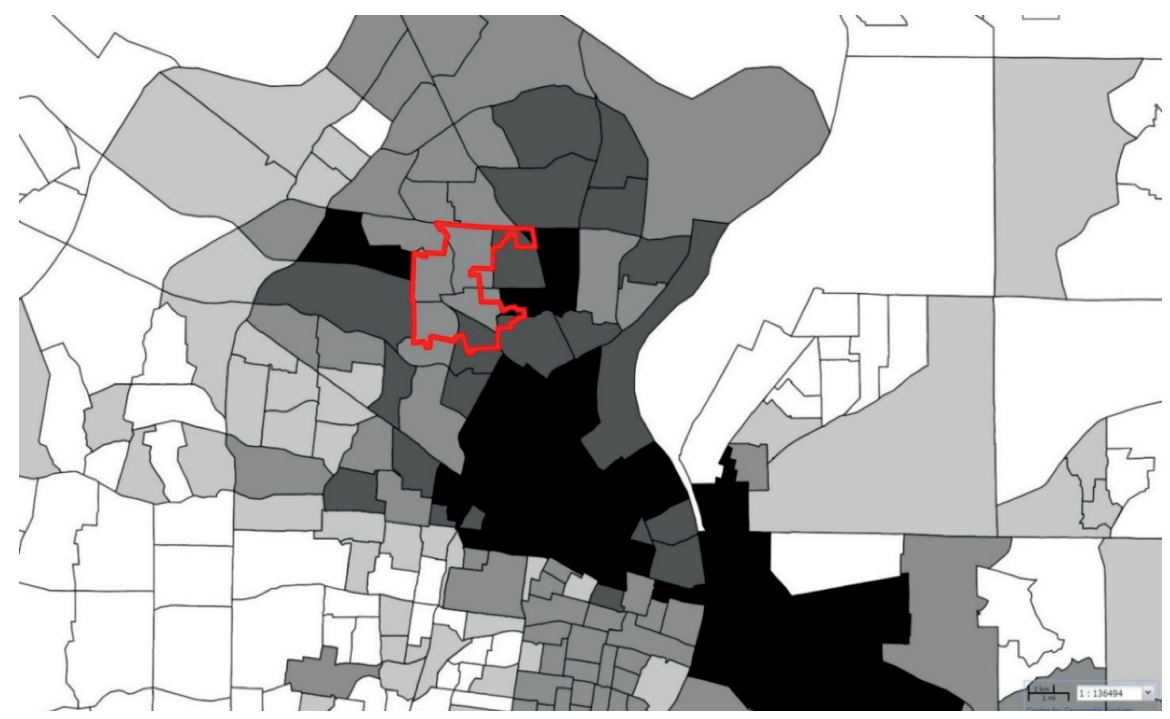




$\square$ African American $<10 \%$
$\square$ African American $10 \%$ to $25 \%$
$\square$ African American $25 \%$ to $75 \%$
$\square$ African American $75 \%$ to $90 \%$
African American $>90 \%$

Thus, this second act in the forty-year spatial and demographic reorganization in the U.S. consists of the deterritorialization of the vanilla suburbs into chocolate suburbs. However, even though this act can be described as the formation of chocolate suburbs, it does not refer only to the replacement of white residents with black residents. Characteristics associated with the desolate inner city, such as high poverty rates, low employment rates, and school segregation, moved to the chocolate suburbs along with the black population, without much change. Not only did this result in a new phenomenon of suburban poverty, it also racialized the area. In the first act, the city had been a racialized space. Urban spaces had been associated with particular qualities and behaviors related to the so-called underclass, such as poverty, laziness, criminal activities, danger, immorality, deteriorating neighborhoods, degradation, obsolescence, and abandonment. ${ }^{17}$ In the second act, however, the city was gentrified while the suburb became the racialized space. Such racialization of the chocolate suburb was accelerated by the suburban neglect that occurred when the local tax coffers were depleted by the flight of whites and the influx of poor blacks. Adel Allen was a black engineer who succeeded in moving to Kirkwood, a white suburb

17 The issue of the underclass was brought to attention by the U.S. sociologist William Julius Wilson, who defined the term as a "heterogeneous grouping of families and individuals who are outside of the mainstream of the American occupational system." The term "underclass" has often been considered race neutral. Actually, however, it is a politically charged term that carries negative connotations. It has been a "code word" for unworthy and undeserving poor black persons. As Linda Burnham points out, it has "served as a summarizing term for black deviance, encompassing, at the least, criminality, promiscuity, irresponsibility, sloth, and dependence." Moreover, the term reflects the long-established tradition in which we think of the poor as "demoralized and denuded of the will and capacity for constructive self-help." See William Julius Wilson, The Truly Disadvantaged: The Inner City, the Underclass, and Public Policy (Chicago, IL: University of Chicago Press, 1987), 8; Alice O'Connor, Poverty Knowledge: Social Science, Social Policy, and the Poor in Twentieth-Century U.S. History (Princeton, NJ: Princeton University Press, 2001), 275; Linda Burnham, "Racism in U.S. Welfare Policy: A Human Rights Issue," in African Americans in the U.S. Economy, eds. Cecilia A. Conrad, John Whitehead, Patrick Mason, and James Stewart (New York, NY: Rowman \& Littlefield, 2005), 310; Michael B. Katz, "Reframing the 'Underclass' Debate," in The "Underclass" Debate: Views from History, ed. Michael B. Katz (Princeton, NJ: Princeton University Press, 1993), 467. 
southwest of St. Louis, before Williams moved to Ferguson. In 1970, he testified at a hearing of the United States Commission on Civil Rights that Kirkwood had become a ghetto very quickly after he moved there and that public services such as street lights and cleaning had soon deteriorated. ${ }^{18}$ His case exemplifies the outcome of suburban neglect and deinvestment that occurred during the deterritorialization of vanilla suburbs.

\section{Vanilla Power and the Reterritorialization of Ferguson}

Ferguson went through a spatial and demographic reorganization process and was transformed from a vanilla suburb to a chocolate suburb. It was there on August 9, 2014, that Michael Brown, an unarmed black teenager, was killed by a twenty-eight-year-old white police officer, Darren Wilson. It was not the first time that white police officers had swung their batons, thrown punches, or shot black people in the United States. During the beating incident of Rodney King in 1991, several white Los Angeles Police Department (LAPD) officers captured King, a black man who was driving a Hyundai Excel and attempting to flee police in a high-speed car chase, pushed him down with batons, and assaulted him with numerous punches and kicks. Just a month before Brown died in Ferguson, people had been shocked by a video that showed a fifty-one-year-old African American woman, Marlene Pinnock, being pushed down and punched numerous times on the side of the highway in broad daylight by a white California Highway Patrol officer of strong physique.

Though not a rare incident, the death of Brown struck a chord: many black Americans began to protest daily, shouting "Hands Up, Don't Shoot!"19 A

18 United States Commission on Civil Rights, Hearing before the United States Commission on Civil Rights: Hearing Held in St. Louis, Missouri, January 14-17, 1970 (Washington, DC: United States Government Printing Office, 1970), 341.

19 The "Hands Up, Don't Shoot" narrative was constructed upon the assertion that Michael Brown was shot to death by police officer Darren Wilson while raising his hands in surrender. However, there were some claims that this narrative is not true and the "Hand Up, Don't Shoot" protest was thus built upon a myth. In particular, after having made an extensive investigation into the confrontation between Brown and Wilson, the United States Department of Justice cleared the officer of any civil rights violation in the shooting death of the black teenager by concluding that "this matter lacks prosecutive merit and should be closed." However, as one of the reviewers of this article commented, the decision of the Department of Justice did not grant indulgence to racist culture and practices among the local police officers that were another topic for investigation. See United States Department of Justice, Investigation of the Ferguson Police Department (Washington, DC: United States Department of Justice, March 4, 2015); United States Department 
few youths threw firebombs at heavily armed officers sent to control the protest, but most protestors continued their nonviolent resistance in streets that were often blanketed by tear gas. Why did the Brown-Wilson shooting occur in Ferguson, and why did the blacks have to voice their anger and frustration for months and months on the streets? As is evident in the cases of Rodney King in Los Angeles in 1991-1992, Eric Garner in New York City in 2014, Freddie Gray in Baltimore in 2015, and Keith Lamont Scott in Charlotte in 2016, police brutality has been the constant that links various forms of civil unrest in modern U.S. history. However, police brutality and shooting in themselves do not fully account for the causes of the widespread civil unrest in Ferguson. The racial transition and suburban poverty that occurred with the deterritorialization of Ferguson meant that there remained a dividing line functioning as a fuse, one which could be ignited easily, even by a modest altercation between whites and blacks. In this analogy, Ferguson was full of dynamite that could explode at any moment. However, this alone also fails to explain what happened in Ferguson in the summer of 2014 because the deterritorialization that occurred in Ferguson is not an exceptional phenomenon. It is currently happening across many U.S. cities and suburbs. What finally lit the fuse in Ferguson? To answer this question, we must look at how the white Americans, who had become a demographic minority, reacted to Ferguson's deterritorialization. We also need to look at which groups had the political power, and at how they reterritorialized Ferguson.

Michael B. Katz, a historian who passed away in August 2014 while Ferguson protestors covered in tear gas were shouting "Hands Up, Don't Shoot!" under the hot summer sun, asks a thought-provoking question in his book Why Don't American Cities Burn? His answer provides a framework for addressing the above questions. Katz's work considers why U.S. cities had not burned since the 1970s, despite the continuing racial tensions

of Justice, Department of Justice Report Regarding the Criminal Investigation into the Shooting Death of Michael Brown by Ferguson, Missouri Police Officer Darren Wilson (Washington, DC: United States Department of Justice, March 4, 2015). For the controversy over the "Hands Up, Don't Shoot" narrative, see Cheryl Corley, "Whether History or Hype, 'Hands Up, Don't Shoot' Endures," National Public Radio, August 8, 2015; Cristian Farias, “'Hands Up, Don't Shoot' Was Not Built on a Lie," New Republic, March 19, 2015; Michelle Ye Hee Lee, “'Hands Up, Don't Shoot' Did Not Happen in Ferguson," Washington Post, March 19, 2015; Jonathan Capehart, “'Hands Up, Don't Shoot' Was Built on a Lie," Washington Post, March 16, 2015; Jack Healy, Sheryl Gay Stolberg, and Vivian Yee, "Ferguson Report Puts 'Hands Up' to Reality Test," New York Times, March 5, 2015. 
and inequalities between blacks and whites. In France, on the other hand, similar hostilities and tensions had led to a riot in 2005. In the United States, according to Katz, white people had fled the cities for the suburbs after the 1970s, thereby significantly removing the dividing lines between blacks and whites in the cities. Moreover, after the 1960s Civil Rights Movement, whites had handed political control of the cities over to blacks and had retained only their rights to businesses, economic interests, and the downtown areas. This process was referred to by Katz as the "ecology of power," one factor he used to explain why collective movements such as those that set major U.S. cities ablaze in the 1960s are no longer in evidence. Of course, a city that had been relinquished to black Americans was often described as a "hollow prize," one that was based on a brittle economic foundation. Nonetheless, the "ecology of power" that brought about the "devolution of control over space to previously marginalized groups" reduced the potential for civil unrest in U.S. cities because black people began to take political control of their own residential areas, at least nominally, and even if they had complaints, they were reluctant to make an overt, collective, and violent display of them against black mayors or black politicians. ${ }^{20}$

Now, going back to Ferguson, why were the blacks in Ferguson angry, and what were they angry about? What had ignited the fire in Ferguson, which had reached its tipping point due to racial transition and suburban poverty? Part of the answer lay in the fact that a shift in the "ecology of power," which Katz used to explain why U.S. cities did not burn again, had not occurred in Ferguson. In the last half-century, the influx of black Americans into Ferguson and the outflow of white Americans had transformed the area into a chocolate suburb with blacks in the majority; however, the whites maintained political control. The color of the suburb had changed to chocolate, but the color of power had remained vanilla. The white minority was still able to monopolize municipal contracts through vanilla power, and the black majority was excluded from these opportunities. ${ }^{21}$ The inevitable result of this disjunction between the chocolate suburb and vanilla power was racial antagonism.

Transfer of power does not, it must be noted, concomitantly remove inequality and racial antagonism between blacks and whites. As was ev-

20 Michael B. Katz, Why Don't American Cities Burn? (Philadelphia, PA: University of Pennsylvania Press, 2012), 83-86.

21 Jeff Smith, "In Ferguson, Black Town, White Power," New York Times, August 17, 2014. 
ident in the case of Tom Bradley, the first black mayor of Los Angeles (1973-1993), the local government was constrained by the federal government. Bradley had immense support from the black people in South Central Los Angeles, and he was able to provide them with economic benefits in return, based on initiatives such as the federal government's anti-poverty programs. However, federal support was cut after the mid-1980s, and Bradley began to make compromises with downtown business interests. ${ }^{22}$ As a result, the black share of the economic pie kept shrinking, and the limits of the local government's power were revealed. Having a black person elected mayor or promoted to the higher ranks of a police department does not in itself address the issues of the black communities. ${ }^{23}$

Nevertheless, when a number of cities were turned over to blacks, they experienced a measurable improvement in public sector employment, and many districts elected black politicians to represent them. Furthermore, there was a substantial increase in the ratio of black persons hired by police departments, which were often a symbol of oppressive authority in these cities. For instance, in 1975, black Americans made up only 22.3 percent of the police force of Detroit, a predominantly black city, but that number increased to 48 percent by $1987 .{ }^{24}$ However, the "ecology of power" never shifted in Ferguson, and the vanilla power maintained its hold in the chocolate suburb. The mayor and the chief of police were both white, and only one out of six city council members was black. The Ferguson school board had six white members, one Latino, and no voice for the black population. The lack of a shift in the "ecology of power" was evident in the racial makeup of the Ferguson police force because only three out of 53 officers were black. This represented just 5.6 percent of the police force, even though Ferguson's population was 67 percent black.

For the white residents who were reduced to a minority, maintaining and exercising power were prerequisites to reterritorializing Ferguson. In the

22 Raphael J. Sonenshein, Politics in Black and White: Race and Power in Los Angeles (Princeton, NJ: Princeton University Press, 1993), 163-175; Ron Curran, "Malign Neglect: The Roots of an Urban War Zone," L.A. Weekly, December 30, 1988 to January 5, 1989, 8-20.

23 Valerie C. Johnson, Black Power in the Suburbs: The Myth or Reality of African-American Suburban Political Incorporation (Albany, NY: State University of New York Press, 2002), 131-143; Roderick Bush, "The Internal Colony Hybrid: Reformulating Structure, Culture, and Agency," in Hybrid Identities: Theoretical and Empirical Examinations, eds. Keri E. Iyall Smith and Patricia Leavy (Leiden, The Netherlands: Brill Publishers, 2008), 148.

24 Katz 2012, 84. 
larger context, this was brought about through both racial discourse and historically institutionalized devices. First, black males, both adults and teens, were regarded as dangerous in the same sense that wild animals or violent criminals are dangerous. ${ }^{25}$ Their skin color alone represented a challenge to authority and reinforced the need to exercise control. ${ }^{26}$ Racist discourse that dehumanized black males was used as an ideological weapon by the whites who were trying to reterritorialize Ferguson. These weapons were wielded to dismiss black Americans' demands for racial equality and as an excuse to justify police violence against blacks. After Wilson fatally shot Brown, the anxiety and fear that Wilson could have felt when confronted by a black man of large build was emphasized, and there was a considerable amount of criticism suggesting that somehow Brown was responsible for his own death. This reveals the extent to which the dehumanization discourse of black males has spread through U.S. society. ${ }^{27}$ Second, the Progressive Era embedded institutionalized strongholds to ensure that white Americans maintained power. In attempting to dismantle political machines in U.S. cities in the early twentieth century, municipal reformers, who believed that local political issues were different from national issues, promoted nonpartisan and off-cycle elections, held not on the same day as presidential elections but in April on odd-numbered years. This schedule discouraged voter interest and ultimately resulted in low black voter turnouts in areas such as Ferguson, thus reducing the likelihood of exorcising vanilla power. ${ }^{28}$ The

25 Conor Friedersdorf, "Ferguson's Conspiracy against Black Citizens: How the City's Leadership Harassed and Brutalized Their Way to Multiple Civil-Rights Violations," Atlantic, March 5, 2015.

26 Dora Apel, “'Hands Up, Don't Shoot': Surrendering to Liberal Illusion," Theory \& Event 17, no. 3 supplement (2014).

27 Tommy J. Curry, "Michael Brown and the Need for a Genre Study of Black Male Death and Dying," Theory \& Event 17, no. 3 supplement (2014).

28 Sarah Anzia, "Missouri's Unfair Election Rules Stack the Deck against Ferguson's Black Residents," Washington Post, August 29, 2014; Brian Schaffner, Wouter Van Erve, and Ray LaRaja, "How Ferguson Exposes the Racial Bias in Local Elections," Washington Post, August 15, 2014. For discussions of the political consequences of off-cycle nonpartisan elections, see also Myron A. Levine, Urban Politics: Cities and Suburbs in a Global Age (New York, NY: Routledge, 2015), 156-157; Sarah Anzia, Timing and Turnout: How Off-Cycle Elections Favor Organized Groups (Chicago, IL: University of Chicago Press, 2014); Zoltan L. Hajnal, America's Uneven Democracy: Race, Turnout, and Representation in City Politics (New York, NY: Cambridge University Press, 2010); Jessica Trounstine, Political Monopolies in American Cities: The Rise and Fall of Bosses and Reformers (Chicago, IL: University of Chicago Press, 2008); Carol A. Cassel, "The Nonpartisan Ballot in the United States," in Electoral Laws and Their Political Consequences, eds. Bernard Grofman and Arend Lijphart (New York, NY: Algora Publishing, 2003), 226-241; Brian Schaffner and Matthew Streb, "The Partisan Heuristic in Low-Information Elections," Public Opinion Quarterly 66 (2002): 
Progressive reformers also granted autonomy to police officers to sever the relationship between the police and political machines in such a way as to prevent politicians from using officers to their own advantage, which led to a lack of civilian reviews of police officers in areas such as Ferguson. ${ }^{29}$ Many parts of the one-hundred-page Investigation of the Ferguson Police Department by the U.S. Department of Justice published in March 2015 describe unjust behavior and violence on the part of police officers as well as collusion between the police, the courts, and public officials to squeeze out the blacks in an attempt to increase revenues ${ }^{30}$ All of these are living proof of the reterritorialization process Ferguson undertook, using its brutal and oppressive vanilla power made possible by the racist discourse on black people on the one hand and the institutionalized strongholds established by Progressivism on the other.

\section{The Next Ferguson}

After the shooting of Michael Brown, shouts of "Hands Up, Don't Shoot!" filled the streets of Ferguson. As usual, mainstream media focused their coverage on looting by black persons and depoliticized their behaviors by criminalizing them. In doing so, the media further supported the false accusations that black people were the cause of Ferguson's problems and exacerbated fearful attitudes toward black Americans. ${ }^{31}$ In addition, black civil rights activist Al Sharpton denounced the anger of blacks as "ghetto pity parties," 32 failing to recognize that the display of anger by Ferguson resi-

559-581; Brian Schaffner, Matthew Streb, and Gerald Wright, "Teams Without Uniforms: The Nonpartisan Ballot in State and Local Elections," Political Research Quarterly 54 (2001): 7-30; Amy Bridges, Morning Glories: Municipal Reform in the Southwest (Princeton, NJ: Princeton University Press, 1997).

29 Eric Garland, "Race and Beyond: Is Trouble in Ferguson a Design Failure of Its Government Structure?" Center for American Progress, November 21, 2014; Jason Rosenbaum, "Who's in Charge Here? For Ferguson and St. Louis County Police, Not Elected Officials," St. Louis Public Radio, August 27, 2014. For the Progressive reforms of the police, see also H. Kenneth Bechtel, State Police in the United States: A Socio-Historical Analysis (Westport, CT: Greenwood Press, 1995); George L. Kelling and Mark H. Moore, "From Political to Reform to Community: The Evolving Strategy of Police," in Community Policing: Rhetoric or Reality, eds. Jack R. Greene and Stephen D. Mastrofski (Westport, CT: Praeger, 1988), 3-25; Eric H. Monkkonen, Police in Urban America 1860-1920 (New York, NY: Cambridge University Press, 1981).

30 United States Department of Justice, Investigation of the Ferguson Police Department. See also Frances Robles, "Ferguson Sets Broad Change for City Courts," New York Times, September 8, 2014.

31 Michelle Smith, "Affect and Respectability Politics," Theory \& Event 17, no. 3 supplement (2014).

32 Monica Davey, “Amid Mourning for Michael Brown, Call for Change,” New York Times, August 25, 2014. 
dents was not commensurable with traditional black political movements, such as encouraging voting and marching. Looting stores is, of course, a form of violent and criminal behavior, and it cannot be denied that some protestors likely participated in the looting spree with opportunistic motives. However, as the riots in the U.S. in the 1960s and 1992 revealed, looting that involves reclaiming others' assets is a form of political behavior that carries with it a message of resistance against the dominant powers, and it is not reducible to just a violent and opportunistic crime. Moreover, the fact that the black residents of Ferguson were taking over the streets and shouting "Hands Up, Don't Shoot!" conveys how limited their opportunities were to participate in politics. Institutionalized politics had placed so many restrictions on their behavior that the only place they could give vent to their anger and frustration was the street..$^{33}$ In addition to the looting, the conduct that mainstream media and established civil rights leaders labeled as disorderly and irrational was the public behavior of black subalterns who participated in such street politics.

Obama's victory in the 2008 presidential election engendered faith that the U.S. was moving into a post-racial, colorblind society. The Ferguson incident showed that this belief was merely a fantasy. Of course, it can also be said that Jim Crow racism with its belief in biological superiority and inferiority has almost receded, although contemporary discourses of race, as Etienne Balibar suggests, still sometimes allow the "return of the biological theme" which finds its chief expression in the notion of "biological (and biophysical) causes and effects of culture, and biological reactions to cultural difference." ${ }^{34}$ Furthermore, as the colorblind discourse implies, the concept of race is not objective and neither is it based on science. Rather, race is a discursive reality created by particular power relations. It is also a type of personal, and at the same time public, imagination and ideology of bodily differences. However, the poverty in the chocolate suburb of Ferguson and its long-standing vanilla power show that although race is an outcome of imagination, it is still a main channel by which material wealth is acquired and an unfair distribution of power occurs. The Ferguson incident may mean that while the U.S. has entered a raceless or post-racial era, it remains a racist society structured by a racial hierarchy and racial antagonisms with the whites still in control.

33 Pinckney 2015.

34 Etienne Balibar, “Is There a 'Neo-Racism'?" in Race, Nation, Class: Ambiguous Identities, eds. Etienne Balibar and Immanuel Wallerstein (New York, NY: Verso, 1991), 26. 
The centrality of the black-white paradigm in such a racial hierarchy is another important point that became evident with the incident in Ferguson. The Los Angeles riots of 1992 identified a need to observe the racial relations in the U.S. from a more complex framework than that of black-andwhite dualism. That riot was a hybrid situation in that it was the outcome of over-determined contradictory conflicts between whites and blacks, Koreans and blacks, and Koreans and Latinos. ${ }^{35}$ However, what Ferguson reveals is that while racial relations in the U.S. are diversifying beyond the black-white dichotomy, such dualism remains at the center of the racial hierarchy. In this sense, the Kerner Commission's assessment that the U.S. was divided into two unequal societies, black and white, is still valid.

To make matters worse, the excessive use of force that is inevitably accompanied by the militarization of the police was responsible for spreading the fire ignited by the shooting death of Brown in Ferguson. The heavily armed officers pointing their guns at the protestors who were shouting "Hands Up, Don't Shoot!," and the heavy firearms that would normally only be seen in war zones were enough to leave the impression that Ferguson is less a suburban community in the heartland of the United States, and more a Middle East battlefield. Militarization of the police force was first attempted by William H. Parker in the 1950s when he was the LAPD chief as an excuse for specializing the police force; it reached its peak under Daryl Gates, who led the department for fourteen years, until the Los Angeles riots of 1992 erupted. During this process of militarization, progressive powers in Los Angeles, such as the Black Panther Party Los Angeles Chapter, were oppressed and targeted ruthlessly by the police, who even resorted to using armored vehicles to accomplish their objectives. The nationwide militarization of the police has been further accelerated under the Obama administration. After Obama declared that it was time to end "long-time wars," heavy firearms that would be used in overseas battlefields such as M16 rifles and grenade launchers were furtively being transformed into domestic weapons, with large quantities of these tools of war finding their way into the hands of police officers. ${ }^{36}$ As documented in the report War Comes Home: The Excessive Militarization of American Policing pub-

35 Mike Davis, "LA: The Fire This Time," Covert Action Information Bulletin 41 (1992): 12; David O. Sears, "Urban Rioting in Los Angeles: A Comparison of 1965 and 1992," in The Los Angeles Riots: Lessons for the Urban Future, ed. Mark Baldassare (Boulder, CO: Westview Press, 1994), 251.

36 Matt Apuzzo, "War Gear Flows to Police Departments," New York Times, June 8, 2014. 
lished by the American Civil Liberties Union only two months before the Brown-Wilson shooting incident, the war is no longer overseas; it is now within the United States. ${ }^{37}$ Places that have been restructured into chocolate suburbs with vanilla power after deterritorialization and reterritorialization are emerging as regions with escalated tensions where war can break out at any moment. Ferguson may represent only the beginning of such a war.

37 American Civil Liberties Union, War Comes Home: The Excessive Militarization of American Policing, June 2014. 